\title{
A STUDY ON ATTITUDE TOWARDS ENGLISH LANGUAGE LEARNING AMONG NON-ENGLISH MAJORED STUDENTS AT TRA VINH UNIVERSITY
}

\section{Duy Thi Thuy Pham, Trang Huynh Nguyen ${ }^{+}$}

\section{Article History}

Received: May 13, 2020

Accepted: August 11, 2020

Published: September 30, 2020

\section{Keywords}

Attitude, cognitive aspect, behavioral aspect, emotional aspect, English language learning
Tra Vinh University, Vietnam

${ }^{+}$Corresponding author • Email: htrang@tvu.edu.vn

\section{INTRODUCTION}

It is undeniable that English has become an international language which is spoken and taught as native, second or foreign language in many nations around the world. However, language acquisition is not an easy process. Especially, in foreign language context, the learning process can be influenced by various factors such as attitude, motivation, anxiety, intelligence, etc. (Garner, 1980; Lehmann, 2006, cited in Shams, 2008). According to Gardner (1985), attitude was one of the factors that impact foreign language learning as students' effort toward language learning depends partly on attitude. This study is carried out to look into attitude as one of the major factors that make learning a foreign language successful. Specifically, we want to investigate non-English majored students' attitude towards learning English language, taking into three aspects of attitude i.e., cognitive, behavioral and emotional and examine the influence of students' gender and specialization on their attitudes towards learning English.

The following research questions will be developed to enable the researchers to reach the objectives of the study:

1. What is the attitudes of non-English majored students at Tra Vinh University towards learning English language in terms of their behavioral cognitive and emotional aspects?

2. Is there any significant difference in non-English majored students' attitude towards learning English language by gender?

3. Is there any significant difference in non-English majored students' attitude towards learning English language by specializations?

\section{LITERATURE REVIEW}

\subsection{Definitions of attitudes}

Attitudes have been defined by several authors in the fields of education and psychology, especially language learning as follows:

According to Likert (1932) as cited in Gardner (1980), attitude is defined as "an inference which is made on the basis of a complex of beliefs about the attitude object". Ajzen (1988) considered attitude as "a disposition to respond favorably or unfavorably to an object, person, institution, or event". Baker (1992) defined attitude as "a hypothetical construct used to explain the direction and persistence of human behavior". An attitude is "a relatively enduring organization of beliefs, feelings, and behavioral tendencies towards socially significant objects, groups, events or symbols" (Hogg \& Vaughan, 2005).

\subsection{The important roles of attitude to language learning}


It is undeniable that attitude plays an important role in enhancing language learning. According to Gardner (1985), attitude was considered as components of motivation in language learning. Brown (2000) concluded that positive attitude towards the self, the native language group, and the target language group enhanced proficiency. Achievement in learning a language depended not only on learners' intelligence but also on learner's attitude. It seemed that everyone from students, teachers, to researchers all agreed that high motivation and positive attitude to a language and its culture contribute to achievements in learning that language (De Bot et al., 2005). According to Choy \& Troudi (2006), attitude could help the learners to express whether they liked or disliked the objects or surrounding situations. It was agreed that the inner feelings and emotions of foreign language learners influenced their perspectives and their attitudes towards the target language. Kara (2009) stated that positive attitude could lead to the exhibition of positive behaviors toward courses of study. Participants absorbed themselves in courses and strived to learn more.

In brief, attitude towards language learning play a vital role, so teachers should understand clearly students' attitude and try to help them to have positive attitude to their language learning process.

\subsection{Aspects of language attitude}

Wenden (1991) stated that attitude included three aspects namely cognitive, affective and behavioral. Firstly, a cognitive aspect involved the beliefs and ideas or opinions of language learners about the knowledge and their understanding in their learning process. The affective one (emotional one) was related to the feeling and emotions of people towards an object. They could express whether they liked or disliked the objects or surrounding situations. Choy \& Troudi (2006) believed that the inner feelings and emotions of language learners influenced their perspectives and their attitudes towards the target language. Finally, the behavioral aspect referred to the way individual behaved and reacted towards an object in particular situations.

McLeod (2009) affirmed that the three components above were known as ABC model and provided more details for the cognitive component. Cognitive component involved a person's belief or knowledge about an attitude object. Regards of cognitive component of language attitudes, it was the beliefs of the language learners about the knowledge that they received and their understanding in the process of language learning. The cognitive attitude could be classified into four steps including of connecting the previous knowledge and the new one, creating new knowledge, checking new knowledge, and applying the new knowledge in many situations. For example, a person may think that English is very useful. Effective component referred to a part of attitude which was related in general emotions or feelings of a person, for example, someone might say I am interested in learning English.

Feng \& Chen (2009) said that learning process was an emotional process. It was affected by different emotional factors. The teacher and his students engaged in various emotional activities in it and varied fruits of emotions are yield. Behavioral component referred to the way the attitude we had influences how we acted or behaved. For example, if a person has positive attitude towards English, he or she may learn English.

It can be inferred that beliefs and feelings are involved in attitudes. It theoretically should influence behaviors, and that is a range of issues about which people have language attitudes.

\subsection{Related studies}

Students' attitudes towards learning foreign languages in general and English in particular were much more concerned in the research studies conducted in many countries. For instance, Benson (1991) had a research about "Attitudes and motivation towards English: A survey of Japanese Freshmen". In this research, more than 300 freshmen were chosen to assess their attitudes to English. There were also parts for self-assessment of English skills, English learning motivation, and the usefulness of English functions. The results reveal that the students who were exposed to English tended to self-rate their own skills extremely low. They rated their understanding and speaking skill lower than reading and writing. Surprisingly, most of them chose personal and integrative reasons for learning English.

Abidin et al. (2012) conducted a research on "EFL students' attitudes towards learning English language. The case of Libyan secondary school students". Unlike Benson (1991), besides investigating 180 Libyan secondary school students' attitudes towards learning English in terms of the behavioral, cognitive and emotional aspects, this research also identified any significant difference in the students' attitudes towards English language based on their demographic profiles i.e., gender, field and year of study. The findings underlined that the attitudes of female secondary school students towards English were slightly higher than that of male ones. The reasons for that may be the variety of English teaching strategies and the classroom activities. It was proposed that the content of the curriculum and the nature of specializations can influence the nature of attitude towards the subjects in general and English 
language in particular. Interestingly, the study concluded that all secondary students from three years showed no difference in their attitudes towards learning. This study provides a basis of the students' attitudes toward learning English. However, it does not show any correlation between the attitudes and learning competence. The research is found in line with Al-Zahrani (2008) who conducted a study to determine the attitudes of students towards English in Saudi. The descriptive statistics showed that the respondents in the three years had the same level of attitude. Similar findings are also found in the study of Nahavandi, \& Mukunda (2013). The aim of this research is to understand motivational orientations of the EFL engineering students to the language and their attitudes to English, Englishspeaking people and their Iranian culture. The respondents showed positive attitudes to target language and its members. 4.66 is the mean of attitudes towards learning English among males and among females is 4.92; therefore, it was concluded that attitudes towards learning English among females were significantly higher than that of males. However, attitudes towards English-speaking people were almost the same between male and female students.

In terms of the correlation between attitude in learning language and the language performance, the findings of some researches are almost contradicted. Take the research conducted by Fakeye (2010) as an example, "Students personal variables as correlates of academic achievement in English as a second language in Nigeria", in this research he attempted to investigate the relationship between attitude and achievement in English among 400 randomly selected senior secondary students from five secondary schools by questionnaire on students' attitude to English and students' academic ability test. The statistical analysis revealed that the students had average positive attitude to English language. However, gap gender in terms of attitude was narrow. Positive relationships between student's attitude and their English language achievement; between academic ability and their English language achievement existed, but they were too low and not significant. However, this runs counter to some findings. For instance, Bidin et al. (2009) carried out a research, which described the relationship between the students' motivation and attitude, and their English language performance suggested that the higher achievers had better attitude in learning English than the low achievers.

Soleimani \& Hanafi (2013) examined a sample of medical students' attitudes towards English language learning in Iran. There was not much new information, but they analyzed more details. Among the 3 aspects of attitudinal components, behavioral aspect experienced the lowest mean score. One example was that when the students were exposed to language environment, they still did not want to practise because learners believed that English language was not important.

The findings of the study by Al-Bustan \& Al-Bustan (2009) on 787 Kuwait University students towards learning English as a foreign language revealed that males and females hold different attitudes towards English learning. There was a significant relation between female students' negative experience with their high school teachers and their negative attitudes. The negative experience resulted from the thought that teachers were not competent enough, or not making enough effort to explain adequately during the course. However, this could not be applied to male students who participated in this study. Another interesting finding from this research is that only female students showed a dependency of rejection of the language. Besides the negative experience with the teachers, they had negative attitudes because of the fact that English in university was found quite different from the English they studied at high school, and English was not used in their major course.

The attitudes of learners towards learning English were also explored by Abu-Snoubar (2017). The sample of the study consisted of 176 students in science and humanity faculties. The study proved that academic field of study was not an effect variable; however, significant differences could be seen between male and female attitudes in learning English.

Wati (2018) studied the language attitudes of undergraduate students of English Education Department in Surakarta Muhamamadiyah University in terms of 3 aspects of attitudes including behavioral, cognitive, and affective aspects and investigated language attitude differences across gender and length of study. The findings showed that the undergraduates had different language attitudes, and there are statistic differences in the undergraduate language attitudes towards English across gender as well as years of study.

In general, different studies do not reveal the same results regarding attitudinal differences concerning genders. It is not clear whether genders can be attributed to higher or lower attitudes that students hold and high and positive attitudes can lead to high achievements.

\section{RESEARCH METHODS AND RESULTS \\ 3.1. Research methods \\ 3.1.1. Research design}


The quantitative research was employed in this study. The participants were asked to answer all the questions in the adapted questionnaire of Abidin et al. (2012).

\subsubsection{Research participants}

There were 89 respondents (46 male students and 43 female students) from 3 main specializations: Office Administration had 31 respondents ( 29 male students and 02 female students), Tourism had 20 respondents ( 02 male students and 18 female students) and Medical Physician had 38 respondents (15 male students and 23 female students). They were second-year students studying English General Course 3 at Tra Vinh University.

Table 1. Description of participants

\begin{tabular}{|c|l|c|c|c|c|c|c|}
\hline \multirow{2}{*}{ No. } & \multirow{2}{*}{ Specializations } & \multicolumn{4}{c|}{ Gender } \\
\cline { 3 - 8 } & & \multicolumn{2}{|c|}{ Male } & \multicolumn{2}{c|}{ Female } & \multicolumn{2}{c|}{ Sum } \\
\cline { 3 - 8 } & & Quantity & Frequency & Quantity & Frequency & Quantity & Frequency \\
\hline 1 & Tourism & 2 & 2.25 & 18 & 20.22 & 20 & 22.47 \\
\hline 2 & Office Administration & 29 & 32.58 & 2 & 2.25 & 31 & 34.83 \\
\hline 3 & Medical Physician & 15 & 16.85 & 23 & 25.84 & 38 & 42.70 \\
\hline & Total & 46 & 51.69 & 43 & 48.31 & 89 & 100.00 \\
\hline
\end{tabular}

\subsubsection{Research instrument}

Attitudes towards learning English were measured by a questionnaire adapted from the questionnaire of Abidin et al. (2012) which consisted of 34 items concerning language attitudes in terms of cognitive aspect (13 items), behavioral aspect (10 items) and emotional aspect of attitudes (11 items). All the items were put in a 5-point Likert scale from 1: Strongly disagree, 2: Disagree, 3: Neutral, 4: Agree to level 5: Strongly agree.

\subsubsection{Procedure}

The data of the study are the attitudes of the respondents given in the questionnaire from strongly disagree to strongly agree. The questionnaires were delivered to students. Then all the questions were collected for data coding and analysis. Statistical Package for the Social Science program (SPSS) version 22.0 was used to analyze the collected data.

\subsection{Research results}

\subsubsection{The reliability of the questionnaire}

Table 2. The reliability of all the items in the questionnaire

$\begin{array}{cc}\text { Cronbach's Alpha } & \text { No. of Items } \\ .810 & 34\end{array}$

To measure the reliability level of the questionnaire items, the reliability coefficient test was done. As can be seen from Table 2, the value of Cronbach's Alpha was 0.810 which shows acceptable consistency of reliability. This means all the questionnaire items can measure the research goals effectively.

\subsubsection{Students' attitudes towards English language learning}

Table 3. Descriptive Statistics of students' attitudes toward English language

\begin{tabular}{|c|c|c|c|c|c|}
\hline Aspects & N & Minimum & Maximum & Mean & Std. Deviation \\
\hline Cognitive aspect & 89 & 2.65 & 4.13 & 3.59 & 0.45 \\
\hline Behavioral aspect & 89 & 2.75 & 3.73 & 3.36 & 0.47 \\
\hline Emotional aspect & 89 & 2.40 & 4.39 & 3.38 & 0.40 \\
\hline Overall & 89 & & & 3.45 & 0.38 \\
\hline
\end{tabular}

The results from Table 3 show that the overall mean score of participants' attitudes towards English language is 3.45 ( $\mathrm{SD}=0.38$ ). This result reveals that the students have average positive attitude towards English. Among the three aspects of language attitudes, the cognitive aspect represents the highest mean score $(\mathrm{M}=3.59, \mathrm{SD}=0.45)$. There is almost no difference between the emotional aspect and behavioral one. $(\mathrm{M}=3.36, \mathrm{M}=3.38$, respectively). 3.2.3. The cognitive aspect of attitude towards English language

As shown in Table 4, the cognitive aspect of attitude towards English language represents the highest mean score $(M=3.59)$. That is, the students have positive beliefs or opinions about English learning. Specifically, most of them are aware of the importance of English in their study and their workplace in the future with the highest mean scores $(\mathrm{M}=4.13, \mathrm{M}=4.11$ respectively), so they expect to learn more English in the future. However, the students still avoid doing homework to improve their study, and they are not confident in applying what they learnt in real situations (with the lowest mean score $\mathrm{M}=2.65$ ). 
Table 4. Descriptive Statistics of Cognitive aspect of Language attitude

\begin{tabular}{|l|c|c|}
\hline \multicolumn{1}{|c|}{ Items } & Mean & Std. Deviation \\
\hline Studying English is important because it will make me more educated & 4.13 & 1.01 \\
\hline Being good at English will help me study other subjects well & 3.73 & 1.03 \\
\hline I have more knowledge and more understanding when studying & 3.72 & 0.98 \\
\hline I look forward to studying more English in the future & 4.11 & 0.90 \\
\hline I put off my English homework as much as possible* & 3.25 & 1.06 \\
\hline I cannot summarize the important points in the English subject content by myself* & 2.81 & 1.12 \\
\hline I am interested in studying English & 3.73 & 1.07 \\
\hline Studying English helps me communicate in English & 4.10 & 0.77 \\
\hline I cannot apply the knowledge from English subject in my real life* & 2.65 & 1.17 \\
\hline Studying English subject makes me feel more confident & 3.69 & 0.93 \\
\hline I like studying English because it will be useful for my future career & 4.11 & 0.84 \\
\hline I enjoy studying English because I like people who speak English & 3.35 & 0.98 \\
\hline I like English because it sounds modern & 3.34 & 1.10 \\
\hline \multicolumn{1}{|c|}{ Total } & 3.59 & \\
\hline
\end{tabular}

(*): Reverse items

\subsubsection{The behavioral aspect of attitude towards English language}

Table 5 reveals that the respondents show a neutral behavioral attitude towards learning English with the lowest mean score of 3.36 among the three variables. They like to do some activities when studying in English classes such as giving opinion and practicing English with other learners. However, they are not comfortable whenever speaking English $(\mathrm{M}=3.03)$.

Table 5. Descriptive Statistics of Behavioral aspect of Language attitude

\begin{tabular}{|c|c|c|}
\hline Items & Mean & Std. Deviation \\
\hline Speaking English anywhere makes me feel worried* & 3.19 & 1.05 \\
\hline Studying English helps me have good relationships with friends & 3.53 & 1.08 \\
\hline I like to give opinions during English lessons & 3.47 & 0.90 \\
\hline I am able to make myself pay attention during studying English & 3.61 & 0.96 \\
\hline $\begin{array}{l}\text { When I hear a student in my class speaking English well, I like to practice speaking } \\
\text { with him/her }\end{array}$ & 3.73 & 1.07 \\
\hline Studying English makes me confident in expressing myself & 3.57 & 0.98 \\
\hline Studying English helps me improve my personality & 3.28 & 0.98 \\
\hline I do not like studying English* & 2.75 & 1.05 \\
\hline I am not relaxed whenever I have to speak in my English* & 3.03 & 1.09 \\
\hline I like to practice English the way native speakers do & 3.47 & 1.05 \\
\hline Total & 3.36 & \\
\hline
\end{tabular}

\subsubsection{The emotional aspect of attitude towards English language}

In general, the mean score of the emotional aspect of attitudes towards English is not high $(\mathrm{M}=3.38)$. As can be seen in Table 6, most of the respondents showed that they preferred communicating with others in English $(\mathrm{M}=$ 3.74). However, almost all the participants admitted that they feel embarrassed when speaking English in their class $(\mathrm{M}=4.39)$. It can be concluded that their feelings or emotions towards English are not positive.

Table 6. Descriptive Statistics of emotional aspect of Language attitude

\begin{tabular}{|l|c|c|}
\hline \multicolumn{1}{|c|}{ Items } & Mean & $\begin{array}{c}\text { Std. } \\
\text { Deviation }\end{array}$ \\
\hline I feel proud when studying English language & 3.56 & 1.02 \\
\hline I feel excited when I communicate in English with others & 3.74 & 1.04 \\
\hline I don't get anxious when I have to answer a question in my English class & 3.04 & 1.08 \\
\hline Studying English makes me have good emotions (feelings) & 3.34 & 1.11 \\
\hline I prefer studying in my mother tongue rather than any other foreign language & 3.29 & 1.28 \\
\hline
\end{tabular}




\begin{tabular}{|c|c|c|}
\hline Frankly, I study English just to pass the exams* & 3.38 & 1.07 \\
\hline I enjoy doing activities in English & 2.43 & 1.08 \\
\hline I feel embarrassed to speak English in front of other students* & 4.39 & 0.80 \\
\hline I wish I could speak English fluently & 3.91 & 0.80 \\
\hline To be honest, I really have little interest in my English* & 2.40 & 0.92 \\
\hline Studying English makes me able to create new thoughts & 3.72 & 0.89 \\
\hline Total & 3.38 & \\
\hline
\end{tabular}

3.2.6. Attitudes towards learning English regarding participants' genders

The results from Table 7 show that the mean score of male students $(\mathrm{M}=3.51)$ is higher than that of female students $(M=3.37)$. Then, an independent-sample-t-test was conducted to compare the effect of genders on the attitudes towards English learning. However, the result reveals that there are no significant differences in the mean score for female students $(M=3.37, S D=0.41)$ and male students $(M=3.51, S D=0.32) ;\left(t=1.79\left\langle t_{05}=1.99, p>\right.\right.$ $0.05)$. These results suggested there is no significant difference in non-English majored students 'attitudes towards learning English language.

Table 7. Descriptive Statistics of attitude towards learning English by Gender

\begin{tabular}{|c|c|c|c|c|c|}
\hline \multicolumn{2}{|c|}{ Gender } & Mean & Std. Deviation & T & P \\
\cline { 2 - 4 } \multirow{2}{*}{ Attitude } & female & 3.37 & 0.41 & \multirow{2}{*}{1.79} & \multirow{2}{*}{$>0.05$} \\
\cline { 2 - 4 } & male & 3.51 & 0.32 & & \\
\hline
\end{tabular}

$\mathrm{t}_{05}=1.99$

3.2.7. Attitudes towards learning English regarding participants' specializations

Table 8. Descriptive Statistics of attitude towards learning English by specializations

\begin{tabular}{|l|r|r|r|r|r|r|r|r|}
\hline & $\mathbf{N}$ & Mean & $\begin{array}{c}\text { Std. } \\
\text { Deviation }\end{array}$ & \multirow{2}{*}{$\begin{array}{c}\text { Std. } \\
\text { Error }\end{array}$} & $\begin{array}{c}\text { 95\% Confidence } \\
\text { Interval for Mean }\end{array}$ & \multirow{2}{*}{ Minimum } & \multirow{2}{*}{ Maximum } \\
& & & & & Bound & $\begin{array}{c}\text { Upper } \\
\text { Bound }\end{array}$ & & \\
\hline Tourism & 20 & 3.15 & .49 & .109 & 2.919 & 3.374 & 1.99 & 3.78 \\
\hline Office administration & 31 & 3.50 & .35 & .062 & 3.369 & 3.622 & 2.24 & 4.15 \\
\hline Medical physician & 38 & 3.57 & .23 & .038 & 3.490 & 3.642 & 2.97 & 4.05 \\
\hline \multicolumn{1}{|c|}{ Total } & 89 & 3.45 & .38 & .040 & 3.368 & 3.526 & 1.99 & 4.15 \\
\hline
\end{tabular}

The results from Table 8 show the mean score of attitudes among medical physician students $(\mathrm{M}=3.57, \mathrm{SD}=$ $0.23)$, higher than the means score of attitudes among the two other groups of students: Office administration students $(\mathrm{M}=3.50, \mathrm{SD}=0.35)$ and Tourism students $(\mathrm{M}=3.15, \mathrm{SD}=0.49)$. It is clear that Medical Physician students showed the highest attitudes towards English learning contrasted with the tourism students who indicated the lowest.

Table 9. Differences between specializations

\begin{tabular}{|l|r|r|r|r|r|}
\hline & $\begin{array}{r}\text { Sum of } \\
\text { Squares }\end{array}$ & \multicolumn{1}{c|}{ Df } & $\begin{array}{c}\text { Mean } \\
\text { Square }\end{array}$ & F & Sig. \\
\hline Between Groups & 2.42 & 2 & 1.208 & 10.307 & .000 \\
\hline Within Groups & 10.08 & 86 & .117 & & \\
\hline Total & 12.49 & 88 & & & \\
\hline
\end{tabular}

One-way ANOVA analysis was to look into the differences in the attitudes of the respondents towards English learning regarding their specializations. The results from Table 9 indicates that there is a difference in language attitude among the three groups of specializations $(\mathrm{F}=10.307, \mathrm{p}=0.000<0.05)$.

Table 10. Multiple comparisons

\begin{tabular}{|c|c|c|c|c|c|c|}
\hline \multirow{2}{*}{ (I)Field } & \multirow{2}{*}{ (J)Field } & \multirow{2}{*}{$\begin{array}{c}\text { Mean } \\
\text { Difference } \\
\text { (I-J) }\end{array}$} & \multirow{2}{*}{$\begin{array}{l}\text { Std. } \\
\text { Error }\end{array}$} & \multirow{2}{*}{ Sig. } & \multicolumn{2}{|c|}{$\begin{array}{c}\text { 95\% Confidence } \\
\text { Interval } \\
\end{array}$} \\
\hline & & & & & $\begin{array}{l}\text { Lower } \\
\text { Bound }\end{array}$ & $\begin{array}{l}\text { Upper } \\
\text { Bound }\end{array}$ \\
\hline \multirow{2}{*}{ Tourism } & Office Administration & -.34898 & .09817 & .002 & -.5831 & -.1149 \\
\hline & Medical Physician & -.41929 & .09456 & .000 & -.6448 & -.1938 \\
\hline Office Administration & Tourism & .34898 & .09817 & .002 & .1149 & .5831 \\
\hline
\end{tabular}




\begin{tabular}{|l|l|r|r|r|r|r|}
\hline & Medical Physician & -.07031 & .08284 & .674 & -.2679 & .1273 \\
\hline \multirow{2}{*}{ Medical Physician } & Tourism & .41929 & .09456 & .000 & .1938 & .6448 \\
\cline { 2 - 7 } & Office Administration & .07031 & .08284 & .674 & -.1273 & .2679 \\
\hline
\end{tabular}

$\left({ }^{*}\right.$ the mean difference is significant at the 0.05 level)

The analysis of Multiple Comparison was also conducted to determine which groups are statistically different. Table 10 shows that the statistical difference is significant between Tourism students, Office Administration students and Medical Physician students $(\mathrm{p}=0.002 \& \mathrm{p}=0.000<0.05)$. However, there is no statistical difference between Office Administration students and Medical Physician students $(\mathrm{p}=0.674>0.05)$. It can be concluded that Tourism students' attitude towards English learning is the lowest although they are the ones who will use English after graduation more than the students from the two other fields of study.

\section{DISCUSSION AND CONCLUSION}

It can be concluded that the students are aware of the importance of English because it is a compulsory subject, and they can easily get a good job if they have English competence. However, they still do not like English much and do not have appropriate "behaviors" to learn English better. For that reason, there should be more research on students' affective perspective, especially attitudes and students' motivation, and what factors influence on their behaviors when learning English. There are many factors that affect students' language attitudes such as accents, lexical diversity, powerful or powerless speech, rate of speech, language intensity, not only gender difference, or economic-value. In some cases, social factors can inform learners' attitudes in a positive way and educational factors can have negative impacts on learners' attitudes (Getie, 2020). The findings are not in line with the study conducted by Abidin et al. (2012) who reported that their respondents showed negative attitudes in all three aspects and differences in the attitudes of the respondents by gender could not be found. It supported the results of the study conducted by Fakeye (2010) whose findings revealed that female and male respondents were different in their attitudes towards learning English. That is females had a higher positive attitude than males did.

Concerning the second and third research questions, the findings of this current study are not consistent with AbuSnoubar's study (2017) whose students showed different attitudes towards learning English in terms of gender, who also found that students had nearly the same attitude in different fields of study.

On the basis of the study results, some teaching implications can be drawn out. Most of the students have positive attitudes towards English, and they are well aware of the importance of learning English. They know that English is a compulsory subject, and English will be useful for their future life. However, they still do not know what to do to make them like English more and become good English learners. Therefore, the roles of an English teacher are important. It is better for the teachers to understand students' feelings and beliefs. Teachers can do a survey before class meetings. Teachers can promote the students' positive attitudes towards English with a variety of activities including choosing appropriate methodologies, capturing students' attention by the teachers themselves (i.e. voice, humor, clothes). Besides, teachers also need to update teaching techniques, apply new information technology in teaching practices to get students more involved in their learning process.

Furthermore, it is also recommended that teachers should consider learners' perceptions and attitudes towards learning in different fields of study. All the students in Tra Vinh University at university study the same curriculum for English; however, their abilities to learn, and their attitudes are different. With tourism students, English teachers need to motivate them to learn, and highlight the importance of learning English. Students should be encouraged to join in English speaking club regularly and teachers should invite foreign volunteering teachers to come to class every week for students have chances to hear the real native voices, and practice speaking in English. In addition, teachers can create an English language environment for students' study by using English songs and films in classes. These can increase the students' attitudes, motivation and maybe language achievements as well.

\section{REFERENCES}

Abidin, M. J. Z., Pour-Mohammadi, M., \& Alzwari, H. (2012). EFL students' attitudes towards learning English language: The case of Libyan secondary school students. Asian Social Science, 8(2), 119-134.

Abu-Snoubar, T. K. (2017). An Evaluation of EFL Students' Attitudes toward English Language Learning In Terms of Several Variables. International Journal of English Language Teaching, 5(6), 18-34.

Ajzen, I. (1988). Attitudes, Personality \& Behaviour. Open University Press. 
Al-Bustan, S. A. \& Al-Bustan, L. (2009). Investigating Students' Attitudes and Preferences towards Learning English at Kuwait University. College Student Journal, 43(2), 454-463.

Al-Zahrani. M. (2008). Saudi secondary school male students' attitudes towards English: An exploratory study. $J$. King Saudi University, Language and Translation, 20, 25-39.

Baker, C. (1992). Attitudes and language. Clevedon: Multilingual Matters.

Benson, M. J. (1991). Attitudes and Motivation Towards English: A Survey of Japanese Freshmen. RELC Journal, 22(1), 34-38. doi:10.1177/003368829102200103

Bidin, Samsiah \& Jusoff, Kamaruzaman \& Abdul Aziz, Nurazila \& Salleh, Musdiana \& Taniza, Tajudin. (2009). Motivation and Attitude in Learning English among UiTM Students in the Northern Region of Malaysia. English Language Teaching, 2(2), 16-20. doi:10.5539/elt.v2n2p16

Brown, H. D. (2000). Principles of language learning and teaching (4 ${ }^{\text {th }}$ ed.). Englewood Cliffs NJ: Prentice-Hall.

Choy, S. C. \& Troudi, S. (2006). An investigation into the changes in perceptions of and attitudes towards learning English in a Malaysian college. International Journal of Teaching and Learning in Higher Education, 18(2), 120-130.

De Bot, K., Lowei, W. \& Verspoor M. (2005). Second language acquisition: An advanced resource book. London: Routledge.

Fakeye, D. (2010). Students' Personal Variables as Correlates of Academic Achievement in English as a Second Language in Nigeria. Journal of Social Sciences, 22, 205-211. doi:10.1080/09718923.2010.11892803

Feng. R. \& Chen, H. (2009). An Analysis on the Importance of Motivation and Strategy in Postgraduates English Acquisition. English Language Teaching, 2(3), 93-97.

Gajalakshmi, (2013). High School Students' Attitude towards Learning English Language. International Journal of Scientific and Research Publications, 3(9), 1-7.

Gardner, R. C., Lalonde, R. N. Moorcroft, R., (1985). The Role of Attitudes and Motivation in second-language learning: Correlational and Experimental Considerations. Language Learning, 35, 207-227.

Gardner, R.C. (1980). On the validity of affective variables in second language acquisition: Conceptual and statistical considerations. Language Learning, 30(2), 255-270.

Gardner, R.C. (1985). Social psychology and second language learning: The role of attitudes and motivation. London: Edward Arnold.

Getie, A. S. (2020). Factors affecting the attitudes of students towards learning English as a foreign language. Cogent Education, 7(1). doi:10.1080/2331186X.2020.1738184

Hogg, M., \& Vaughan, G. (2005). Social Psychology (4 ${ }^{\text {th }}$ edition). London: Prentice-Hall.

Hussein, G., Demirok, M., \&ss Uzunboylu, H. (2009). Undergraduate student's attitudes towards English language. Procedia - Social and Behavioral Sciences, 1(1), 431-433. World Conference on Educational Sciences: New Trends and Issues in Educational Sciences.

Kara, A. (2009). The Effect of a "Learning Theories' Unit on Students" Attitudes towards Learning. Australian Journal of Teacher Education, 34(3), 100-113.

Lambert, W. E. (1967). A social psychology of bilingualism. Journal of Social Issues, 23 (2), 91-109.

McLeod, S. A. (2018). Attitude measurement. Simply Psychology. Retrieved from https://www.simplypsychology.org/ attitude-measurement.html.

Nahavandi, N., \& Mukundan, J. (2013). Iranian EFL engineering students' motivational orientations towards English language learning along gender and further education in language institutes. International Journal of Linguistics, 5(1), 72-93.

Sayadian, S., \& Lashkarian, A. (2010). Investigating attitude and motivation of Iranian university learners toward English as A foreign language. Contemporary Issues in Education Research, 3(1), 137-147.

Sham, M. (2008). Students' attitudes, motivation and anxiety towards English language learning. Journal of Research, 2(2), 121-144.

Soleimani H., Hanafi S. (2013). Iranian Medial Students' Attitude Towards English Language Learning. International Research Journal of Applied and Basic Sciences, 4(11), 3816-3823.

Wati, S. (2018). Language attitude of undergraduate students towards English at English Education Department. LingTera, 5(1), 10-18. doi:10.21831/lt.v5i1.8583

Wenden, A. (1991). Learner Strategies for Learner Autonomy. London: Prentice Hall. 